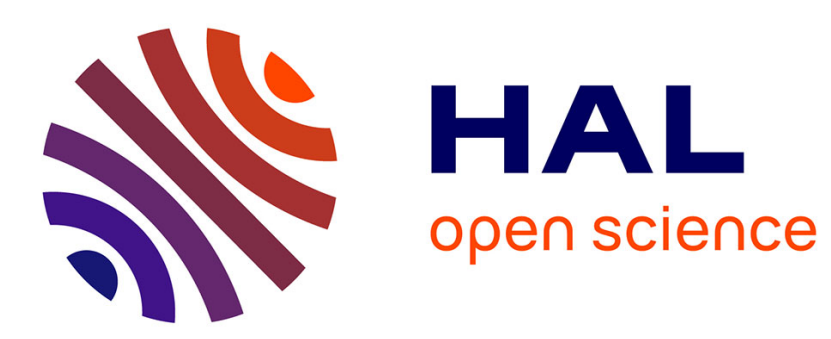

\title{
Proposed mechanisms of toluene removal by vermicompost and earthworms Eisenia fetida
}

Nicolas Lusinier, Catherine Couriol, Pierre Le Cloirec

\section{To cite this version:}

Nicolas Lusinier, Catherine Couriol, Pierre Le Cloirec. Proposed mechanisms of toluene removal by vermicompost and earthworms Eisenia fetida. Environmental Technology, 2020, 41 (23), pp.3023-3031. 10.1080/09593330.2019.1595164 . hal-02087808

\section{HAL Id: hal-02087808 \\ https://hal-univ-rennes1.archives-ouvertes.fr/hal-02087808}

Submitted on 13 May 2019

HAL is a multi-disciplinary open access archive for the deposit and dissemination of scientific research documents, whether they are published or not. The documents may come from teaching and research institutions in France or abroad, or from public or private research centers.
L'archive ouverte pluridisciplinaire HAL, est destinée au dépôt et à la diffusion de documents scientifiques de niveau recherche, publiés ou non, émanant des établissements d'enseignement et de recherche français ou étrangers, des laboratoires publics ou privés. 
Publisher: Taylor \& Francis \& Informa UK Limited, trading as Taylor \& Francis Group

Journal: Environmental Technology

DOI: 10.1080/09593330.2019.1595164

Proposed mechanisms of toluene removal by vermicompost and earthworms Eisenia fetida

Nicolas Lusinier ${ }^{\mathrm{a}}$, Catherine Couriol ${ }^{\mathrm{b}, *}$, Pierre Le Cloirec ${ }^{\mathrm{a}}$

${ }^{a}$ Univ Rennes, Ecole Nationale Supérieure de Chimie de Rennes, CNRS, UMR 6226, 11

Allée de Beaulieu, CS 50837, 35708 Rennes Cedex 7, France

${ }^{\mathrm{b}}$ Univ Rennes, CNRS, UMR 6226, IUT, 3 Rue du Clos Courtel, 35704 Rennes Cedex 7 , France

*Corresponding author: catherine.couriol@univ-rennes1.fr

\begin{abstract}
For potential use in air treatment by biofiltration, a new material composed of vermicompost and earthworms (Eisenia fetida) was tested for the removal of a volatile organic compound (VOC), toluene. The removal rate of toluene was measured during batch experiments in presence of vermicompost only, earthworms only and a mixture of both. In the chosen experimental conditions, no mortality of earthworms was recorded and the results showed that the presence of earthworms allowed an increase in toluene removal rate $\left(0.213 \mathrm{mg} \cdot \mathrm{h}^{-1}\right)$ compared to vermicompost only $\left(0.084 \mathrm{mg} \cdot \mathrm{h}^{-1}\right)$ and earthworms only $\left(0.136 \mathrm{mg} \cdot \mathrm{h}^{-1}\right)$. From the experimental data, mechanisms of toluene transfer and adsorption/biodegradation by microorganisms from vermicompost and/or earthworms were proposed.
\end{abstract}




\section{KEYWORDS}

Vermicompost; Vermifiltration; VOC; Mechanisms; Toluene

\section{INTRODUCTION}

Biofiltration is widely used for the treatment of odorous and/or volatile organic compounds (VOCs). A large number of studies have been published on this process [1-5]. The gaseous effluent passes through a fixed film bioreactor. Pollutants contained within it are transferred to the biofilm present in the packing material and oxidized or converted into biomass by microorganisms [6-8]. The degradation of the pollutants leads to the production of metabolic by-products, carbon dioxide and water. The packing material can be organic or inorganic, natural or synthetic $[9,10]$. As this material acts as a support for the biomass and a possible adsorbent for the pollutant, it has to be selected carefully [11-13]. Physico-chemical and mechanical properties must be taken into account. Organic materials, like compost, peat, wood mulch, and pine bark, are often used due to their ability to support bacteria and supply nutrient to the biomass $[14,15]$. However, they have poor mechanical properties and are subject to settling and the generation of preferential pathways [16]. For these various reasons, a mixture of organic and inorganic material is often employed [8,17]. The main role of the inorganic material (pozzolan, porous pebbles, activated carbon, etc.) is to increase the structural stability over time.

Vermiprocesses are emerging techniques used for composting [18-22] and wastewater treatment $[23,24]$. They have also been studied for the treatment of some industrial effluents such as beverage, distillery or paper mill wastewater $[25,26]$. These processes are based on the ability of earthworms (Eisenia fetida) to convert organic matter into compost (called vermicompost or vermicast) by transit through their gut.

Thus, an original packing material composed of vermicompost and earthworms could be tested for the filtration of waste gas. The physico-chemical properties of vermicompost 
(surface $\mathrm{pH}$, water hold-up capacity, organic matter content, density, external porosity) seem to be interesting in terms of biomass development [27-31]. The disadvantage of settling could be solved by the addition of earthworms. The mixing of the vermicompost due to earthworm burrowing activity could guarantee good homogenization of the fixed bed, an optimal distribution of the gaseous effluent inside the biofilter, and good oxygen transfer to the biomass. In this case, earthworms would play the role of inorganic material, i.e. structural agents. Moreover, they could participate in pollutant degradation and increase the efficiency of the biofilter.

The aim of this experimental work was to propose mechanisms of pollutant transfer and degradation by a VOC removal system packed with a vermicompost colonized by earthworms. The rates of degradation of a pollutant by vermicompost, earthworms, and a mixture of both, respectively, were compared in batch experiments. From the data generated experimentally, potential mechanisms were proposed.

\section{MATERIALS AND METHODS}

\subsection{Vermicompost and earthworms}

The earthworms used were Eisenia fetida, which were fed on domestic wastes (fruits/ vegetables wastes and coffee grounds). The vermicompost obtained was then matured for about 3 months before being used in the experiments. The physico-chemical and biological characteristics of the matured vermicompost are presented in Table 1. The significant humidity and presence of bacteria in the vermicompost can be noted. 


\begin{tabular}{|c|c|}
\hline $\mathrm{pH}$ & 8.9 \\
\hline Humidity (\%) & 81 \\
\hline Density $\left(\mathrm{kg} . \mathrm{m}^{-3}\right)$ & 530 \\
\hline Bed porosity $(\%)$ & 35 \\
\hline Water hold-up capacity (g.g ${ }^{-1}$ dry & \\
\hline Cell number (UFC. $\mathrm{g}^{-1}$ dry ver & \\
\hline \multicolumn{2}{|c|}{ Soluble Total Organic Carbon (mgC. $\mathrm{g}^{-1}$ dry vermicompost) } \\
\hline Soluble Total Nitrogen $\left(\mathrm{mgN} \cdot \mathrm{g}^{-1} \mathrm{dr}\right.$ & 3.27 \\
\hline$\% \mathrm{C}$ & 36.7 \\
\hline$\% \mathrm{~N}$ & 5.3 \\
\hline $\mathrm{C} / \mathrm{N}$ & 6.9 \\
\hline
\end{tabular}

Table 1: Physico-chemical properties of vermicompost

\subsection{Target volatile organic compound (VOC)}

Toluene was chosen as a model of volatile organic compounds (VOCs). It has been widely studied as a model molecule in biofiltration processes [32,33]. Some of its physico-chemical characteristics are: formula: $\mathrm{C}_{7} \mathrm{H}_{8}$, molecular weight: 92.17 g. $\mathrm{mol}^{-1}$, solubility in water $\left(25^{\circ} \mathrm{C}\right)$ : 0.53 g. $\mathrm{L}^{-1}$, density: 0.867 and saturated vapor pressure $\left(20^{\circ} \mathrm{C}\right): 3 \mathrm{kPa}$.

\subsection{Batch experiment procedures}

Batch experiments were performed at room temperature $\left(20 \pm 2{ }^{\circ} \mathrm{C}\right)$ in $1 \mathrm{~L}$ conical flasks hermetically sealed with a septum. Several flasks were filled with $100 \mathrm{~g}$ of vermicompost (or $10 \mathrm{~g}$ of adult earthworms or both). The earthworms used in this study were collected from the 
laboratory nursery just before the beginning of the experiment, rinsed with distilled water and wiped before being placed in the conical flasks. They were weighed but not counted.

The pollutant, $5 \mu \mathrm{L}(4.33 \mathrm{mg})$ of toluene (Sigma Aldrich - purity $\geq 99.8 \%$ ) was injected through the septum. This quantity of toluene in gas phase was chosen in order to easily approach the mechanisms and the impacts of VOC on this biotic system. After injection, the conical flasks were manually stirred.

Some preliminary experiments (data not shown) gave the authors an idea of the kinetic of toluene consumption by vermicompost, earthworms or both. The initial number of flasks and sampling timing were decided according to these preliminary results, as well as the mass of vermicompost and the mass of earthworms used. The mass of earthworms was chosen so that the initial quantity of oxygen in the sealed flask was sufficient to allow their breathing during the entire duration of the experiment. It was verified that no earthworm died during the experiment.

At each sampling time, the toluene concentration in the head space of the conical flask was measured in order to calculate the mass remaining in the gaseous phase (see 2.4). Then, the flask was opened and a random sample of the solid phase (vermicompost and/or earthworms) was collected in order to determine the mass adsorbed. The solid (precisely weighed) was put in a hermetically sealed vial and placed in a stove. After total toluene desorption, the head space of the vial was analyzed (see 2.4). Considering the volume of the head space and the toluene concentration measured by GC FID analysis, the mass of toluene adsorbed on the solid could be calculated. The temperature of the stove, the time of desorption and the amount of solid placed in the vial were previously optimized (data not shown) to ensure the total desorption of the toluene. The optimal conditions were the following: mass to be desorbed: about $2.00 \mathrm{~g}$ for vermicompost and about $0.20 \mathrm{~g}$ for earthworms, temperature of desorption: $95^{\circ} \mathrm{C}$ and time of desorption: $5 \mathrm{~h}$. 
Then, the mass of toluene removed was calculated according to the mass balance of the VOC in the system (Equation 1).

$$
M_{\text {total removed }}=M_{\text {initial }}-M_{\text {gaseousphase }}-M_{\text {adsorbed }} \quad \text { Equation } 1
$$

where $M_{\text {initial }}$ is the mass of toluene initially and manually injected in the system through the septum (4.33 mg), $M_{\text {gaseousphase }}$ is the mass of toluene remaining in the gaseous phase of the conical flask and $M_{\text {adsorbed }}$ is the mass of toluene absorbed on the solid phase (vermicompost and/or earthworms).

Due to the experimental conditions (experiments performed in hermetically sealed flasks), and assuming that no leak could occurred, the mass of toluene removed $\left(M_{\text {total removed }}\right)$ corresponded to the mass of toluene consumed by the microorganisms (and/or earthworms) for their growth (toluene was then the carbon source). The kinetics of toluene removal were performed for different operating conditions in order to investigate the transfer of pollutant into the vermicompost and its biodegradation by microorganisms such as bacteria, fungus... present on the vermicompost surface or earthworms when present in the medium.

\subsection{Analyses}

Different analysis methods are available to quantify VOC and especially toluene in gas phase [34]. For example, the use of sorbent material of which analysis is carried out by either thermal desorption (TD) or solvent extraction. Considering the concentrations and because only one VOC was used, a simple method was chosen. Analyses of the gaseous phase (head space of the conical flask and head space of the vial) were performed by Gas Chromatography with a FID detector on a Thermo Fisher Focus GC. The column was an Agilent HP-5, $30 \mathrm{~m} \times 0.32 \mathrm{~mm}$, the oven temperature was $100^{\circ} \mathrm{C}$, the inlet temperature was $150^{\circ} \mathrm{C}$, the detector temperature was $280^{\circ} \mathrm{C}$ and the carrier gas was $\mathrm{N}_{2}$. Analyses were triplicate and the mass were calculated with the average concentrations. 


\section{RESULTS AND DISCUSSION}

3.1 Adsorption-biodegradation of toluene by vermicompost

First, experiments were performed using vermicompost as the potential adsorbent material. Chiu et al. [35] have shown that toluene vapor can be adsorbed onto natural organic matter and especially compost. Several flasks were filled with vermicompost and then toluene was injected into each of them at the same time. The toluene concentration in the gaseous phase was measured as a function of time and the flask was opened to take a sample for vermicompost desorption procedure. The mass of toluene in the gaseous phase, the mass of toluene adsorbed and the mass of toluene consumed (calculated according to the mass balance in Equation 1) were plotted vs. time (Figure 1).

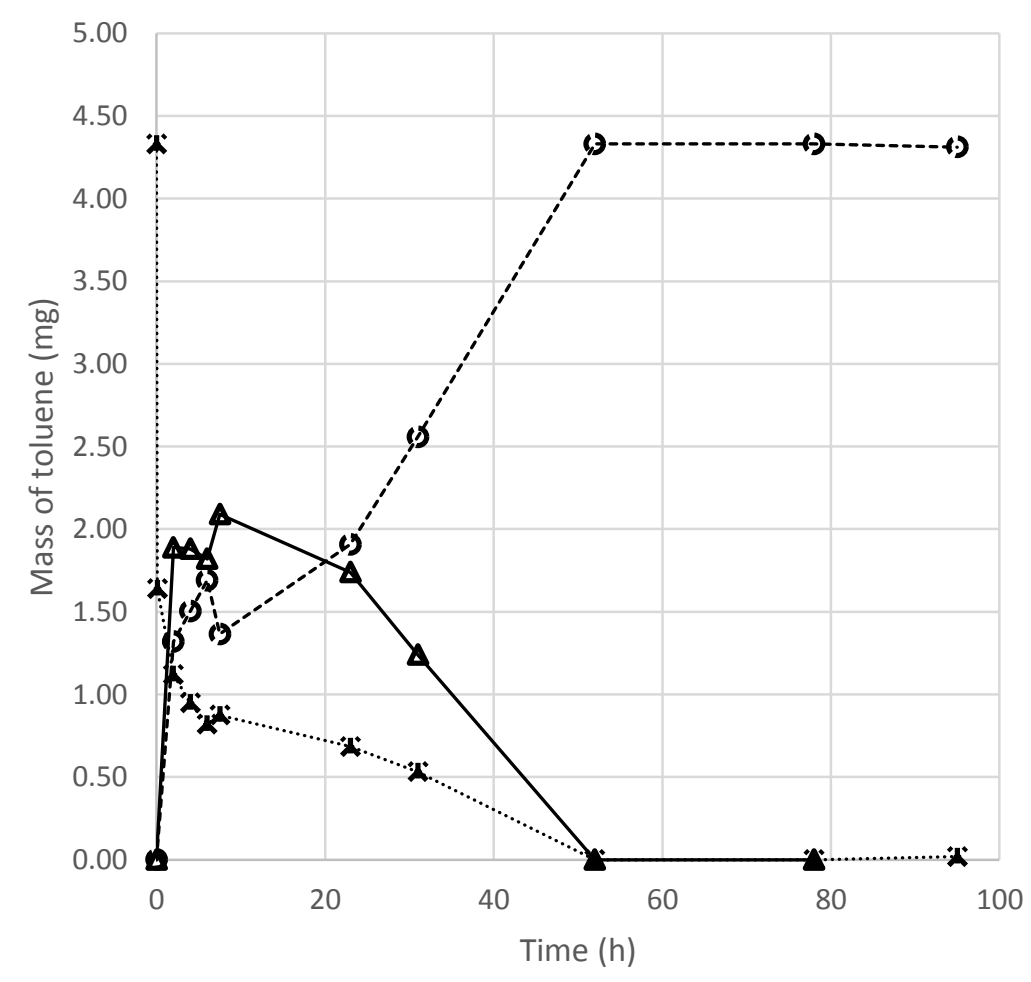

.......... Mass in the gaseous phase

$\triangle$ Mass adsorbed

$--\rightarrow--$ Mass consumed 
Figure 1: Evolution (chain reactions) of mass of toluene in the gaseous phase, mass adsorbed and mass consumed by $100 \mathrm{~g}$ of vermicompost as a function of time.

Figure 1 shows the evolution (chain reactions) of toluene during the successive steps in the reactor. First, there was a rapid decrease in the toluene concentration in the gaseous phase. This behavior was due to both adsorption on the surface of the solid material and consumption by the bacteria present in the vermicompost during the first $10 \mathrm{~h}$. Equation 2 represents the phenomena occurring during this first phase.

$\mathrm{T}+(\mathrm{C}+\mathrm{X}) \longrightarrow \mathrm{T}_{1} \mathrm{C}+\left(\mathrm{X}+\Delta \mathrm{X}_{1}\right)+\mathrm{B}+\mathrm{T}_{2}$ Equation 2

where $\mathrm{T}$ is the initial mass of toluene, $\mathrm{C}$ is the compost mass and $\mathrm{X}$ is the biomass (microorganisms from the vermicompost). A part of toluene $\left(\mathrm{T}_{1}\right)$ is adsorbed on the vermicompost $\left(\mathrm{T}_{1}<\mathrm{T}\right)$. Another part is consumed by microorganisms and leads to an increase in the biomass $\left(\Delta \mathrm{X}_{1}\right)$ and by-products $(\mathrm{B})$. The remaining mass of toluene in the gaseous phase is called $\mathrm{T}_{2}$.

After $20 \mathrm{~h}$ of experiment, the mass adsorbed and the mass in the gaseous phase both decreased. At the same time, the mass removed by the vermicompost increased linearly as a function of time. After $50 \mathrm{~h}$, the toluene was fully consumed by the vermicompost. Equation 3 represents the phenomena occurring during the second phase.

$\mathrm{T}_{1} \mathrm{C}+\left(\mathrm{X}+\Delta \mathrm{X}_{1}\right)+\mathrm{B}+\mathrm{T}_{2} \longrightarrow\left(\mathrm{X}+\Delta \mathrm{X}_{1}+\Delta \mathrm{X}_{2}\right)+\mathrm{B}_{1}+\mathrm{C} \quad$ Equation 3

The adsorbed toluene $\left(T_{1}\right)$ is consumed by microorganisms and the biomass increases $\left(\Delta X_{2}\right)$ as do the by-products $\left(B_{1}>B\right)$. As soon as $T_{1}$ is consumed, the gaseous toluene $T_{2}$ can be adsorbed and then consumed. At the end of the experiment, the toluene was totally consumed and the vermicompost (C) was free of toluene.

During the linear phase (calculated between $23 \mathrm{~h}$ and $52 \mathrm{~h}$ ), a consumption rate of $0.084 \mathrm{mg} \cdot \mathrm{h}^{-1}$ was recorded, corresponding to $4.4 \mu \mathrm{g} \cdot \mathrm{g}^{-1}$ dry weight. $\mathrm{h}^{-1}$. As vermicompost presents variable 
physico-chemical characteristics depending on the raw material used, it is very difficult to compare these results with those found in the literature. However, some discussions and comparisons with previous studies can be made. Vermicompost has previously been used in a mixture with rice paddy soil for methane removal [36], in a mixture with powdered activated carbon for methane removal [37] or for ethylene removal [38] but never for toluene removal. Park et al. [37] recorded a methane oxidation rate of $9.7 \mathrm{~g} \cdot \mathrm{m}^{-3} \cdot \mathrm{h}^{-1}$ while Moon et al. [36] obtained $17.9 \mathrm{~g} \cdot \mathrm{m}^{-3} \cdot \mathrm{h}^{-1}$. Moreover, the authors proved that $\mathrm{CO}_{2}$ and $\mathrm{H}_{2} \mathrm{O}$ were the endproducts and that the amount of $\mathrm{CO}_{2}$ produced was less than the amount of methane oxidized, contributing to reducing greenhouse gas production. In the case of ethylene, $\mathrm{Fu}$ et al. [38] demonstrated that the pollutant removal was due to microbial activity and not to physicochemical properties. A maximum rate of $2.6 \mu \mathrm{g} . \mathrm{g}^{-1}$ dry weight. ${ }^{-1}$ was recorded during batch tests performed at $30^{\circ} \mathrm{C}$. Rates were higher at 20 and $25^{\circ} \mathrm{C}$ and lower at 10 and $40^{\circ} \mathrm{C}$. It should be noted that the rates obtained for methane and ethylene removal were calculated after a lag phase, which was not the case for toluene removal in the present study.

Removal of gaseous toluene has been widely studied over the past years and it is known that many bacteria (Pseudomonas sp., Rhodoccocus, Achromobacter) can degrade toluene by a heterotrophic pathway. The use of a bacterial consortium has enabled good performances in different kinds of bioprocess. Concerning biofiltration, several packing materials inoculated with activated sludge [39-42] have produced elimination rates ranging from 95 to $100 \%$ for loadings ranging from 50 to $200 \mathrm{~g} \cdot \mathrm{m}^{-3} \cdot \mathrm{h}^{-1}$. Cheng et al. [43] demonstrated that a fungal/bacterial biofilter showed better removal $\left(142 \mathrm{~g} \cdot \mathrm{m}^{-3} \cdot \mathrm{h}^{-1}\right.$ with an Empty Bed Retention Time of $24 \mathrm{~s}$ ) than a fungal or bacterial one. Moreover, it produced less $\mathrm{CO}_{2}$ than a bacterial one due to the presence of fungi. As the vermicompost used in the present study contained many microorganisms (1.95 $10^{6} \mathrm{UFC}_{\mathrm{g}} \mathrm{g}^{-1}$ dry vermicompost), it was neither inoculated nor acclimated before experiments. This could explain the relatively low elimination capacity 
(about 1 g. $\mathrm{m}^{-3} \cdot \mathrm{h}^{-1}$ ) recorded for vermicompost. However, some preliminary tests (data not shown) indicated that better performances could be obtained after an acclimation period.

\subsection{Removal of toluene by earthworms}

The second experiment was performed with $10 \mathrm{~g}$ of earthworms. The same experimental procedure as previously described (several flasks) was used. At the end of the experiment, we noted that all earthworms were still alive. The LD50 or LC50 data for Eisenia fetida were not found in the literature. LD50 and LC50 are the Lethal Dose (amount of a material which causes the death of $50 \%$ of a group of test animals) and the Lethal Concentration (concentration of the chemical in air that kills $50 \%$ of the test animals during the observation period (4h)), respectively.

But we note that the acute inhalation toxicity for the rat (LC50) for $4 \mathrm{~h}$ was more than 20 $\mathrm{mg} / \mathrm{L}$. This value has to be compared to the concentration of toluene in this present work which was $4.33 \mathrm{mg} / \mathrm{L}$. Figure 2 shows the results obtained. 


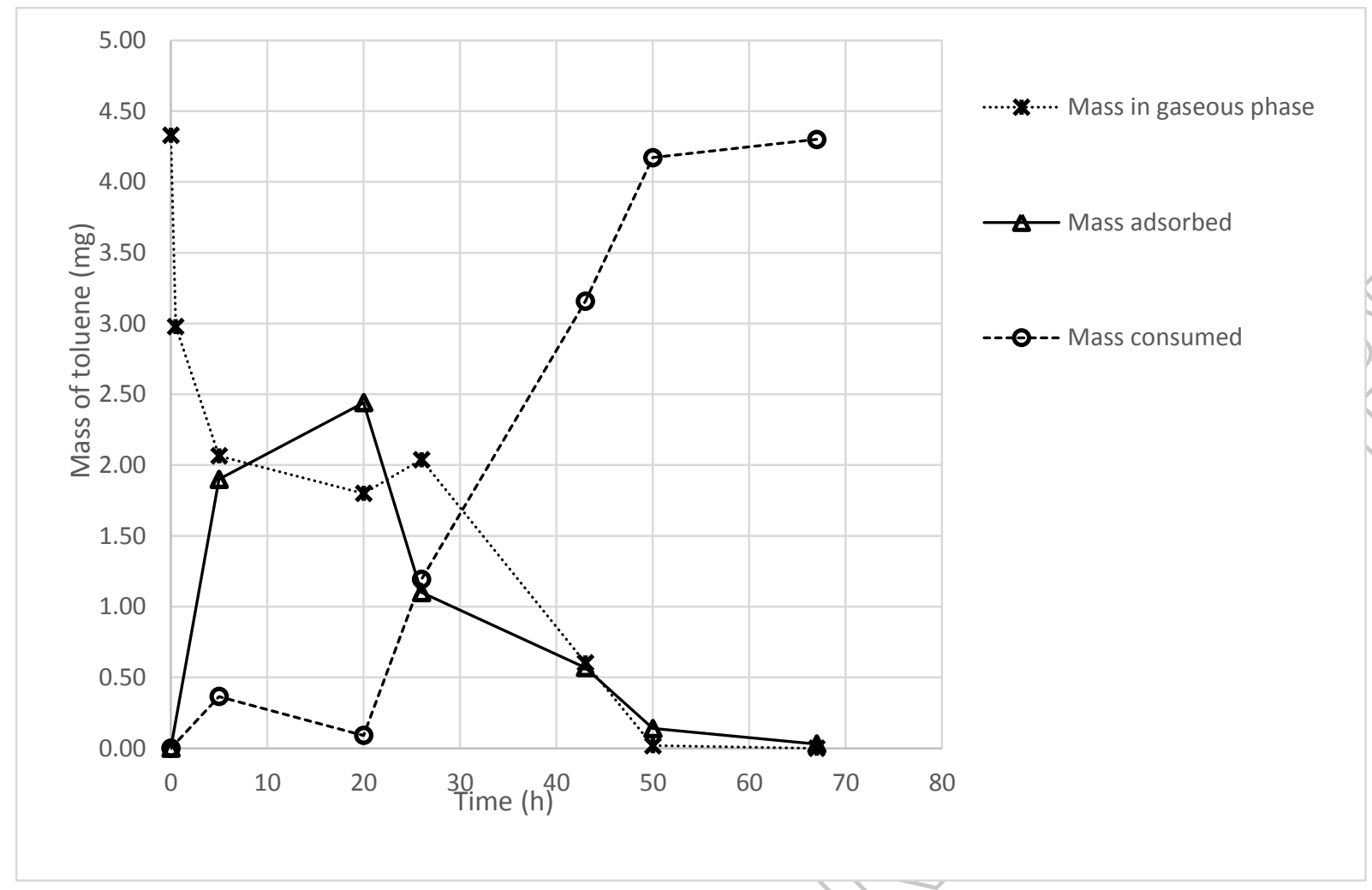

Figure 2: Evolution (chain reactions) of mass of toluene in the gaseous phase, mass adsorbed and mass consumed by $10 \mathrm{~g}$ of adult earthworms as a function of time.

During the first $20 \mathrm{~h}$, the mass of toluene in the gaseous phase decreased, due to adsorption only. No consumption was recorded during this lag phase. During this phase (Equation 4), a part of toluene $\left(\mathrm{T}_{1}\right)$ was adsorbed onto the earthworm (W) surface and the other part $\left(\mathrm{T}_{2}\right)$ remains in the gaseous phase $\left(\mathrm{T}=\mathrm{T}_{1}+\mathrm{T}_{2}\right)$.

$\mathrm{T}+\mathrm{W} \rightarrow\left(\mathrm{WT}_{1}\right)+\mathrm{T}_{2} \quad$ Equation 4

Between $20 \mathrm{~h}$ and $50 \mathrm{~h}$, the mass of toluene consumed increased linearly with time. At the same time, a decrease in the mass adsorbed was observed. After $50 \mathrm{~h}$, the toluene was fully consumed by earthworms. Equation 5 represents the phenomena occurring during the second phase.

$\left(\mathrm{WT}_{1}\right)+\mathrm{T}_{2} \rightarrow(\mathrm{W}+\Delta \mathrm{W})+\mathrm{D} \quad$ Equation 5 
The toluene adsorbed $\left(T_{1}\right)$ was consumed by earthworms. Then $T_{2}$ could be adsorbed and consumed. The toluene degradation led to an increase in earthworm weight $(\Delta \mathrm{W})$ and byproduct formation (D).

During the linear phase (between $20 \mathrm{~h}$ and $50 \mathrm{~h}$ ), a consumption rate of $0.136 \mathrm{mg}$ of toluene per hour (13.6 $\mu \mathrm{g} . \mathrm{g}^{-1}$ fresh earthworm. $\left.\mathrm{h}^{-1}\right)$ was recorded. Wen et al. [44] studied the accumulation and elimination kinetics of ciprofloxacin in earthworms Eisenia fetida and showed an increase in the concentration during the first 7 days followed by a decrease until 30 days, as it was the case for toluene. On the other hand, only an accumulation phase was observed by Nyholm et al. [45] during a 30-day exposure of earthworms to several brominated chemicals (flame retardants).

3.3 Toluene removal by a mixture of vermicompost and earthworms A third experiment was performed with $100 \mathrm{~g}$ of vermicompost and $10 \mathrm{~g}$ of adult earthworms. The results are presented in Figure 3. 


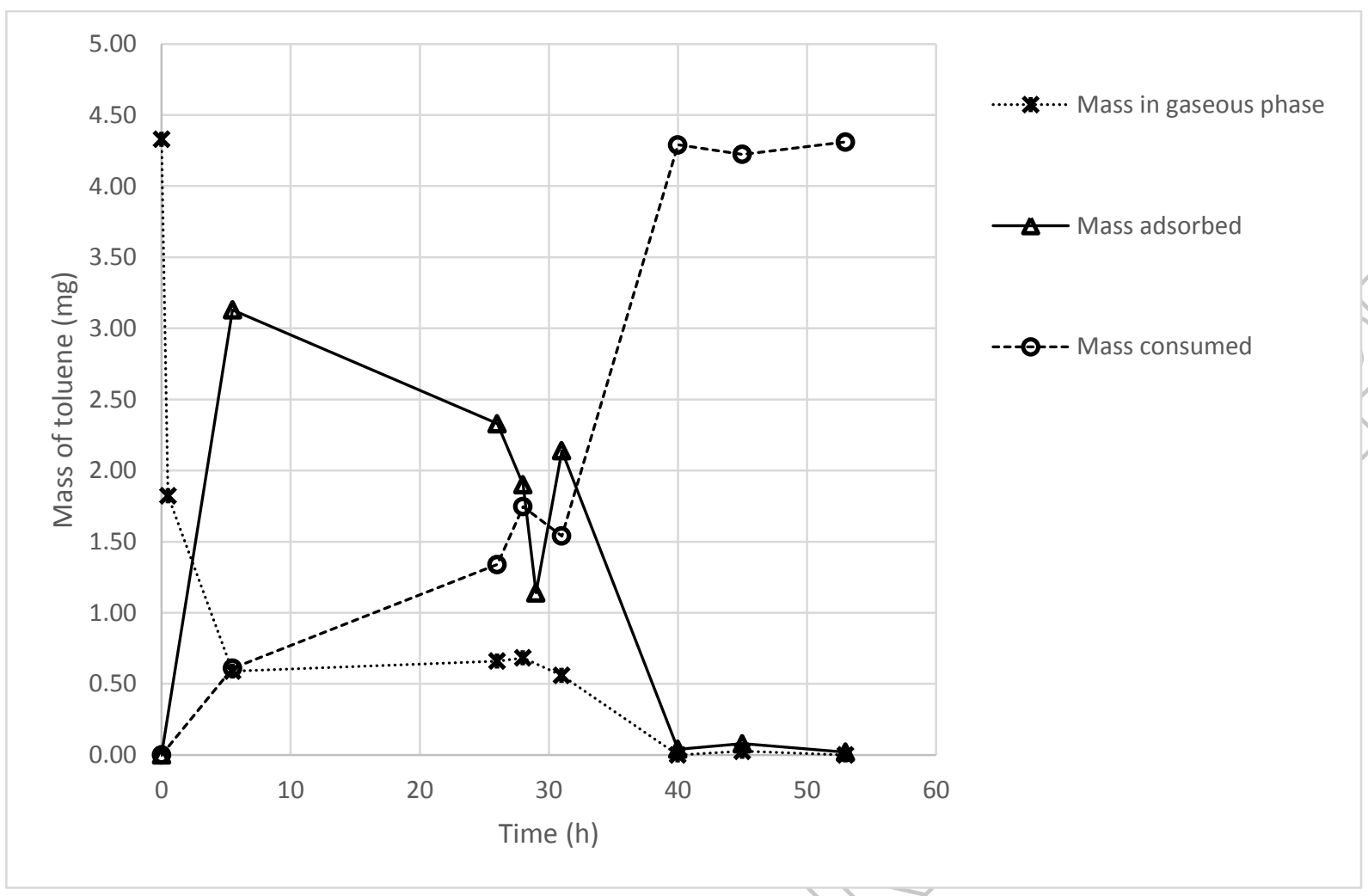

Figure 3: Evolution (chain reactions) of mass of toluene in the gaseous phase, mass adsorbed and mass consumed by $100 \mathrm{~g}$ of vermicompost $+10 \mathrm{~g}$ of adult earthworms as a function of time.

It was observed that the result of this experiment was the addition of the two previous ones i.e. adsorption of about $1.5 \mathrm{mg}$ of toluene during the first phase $(20 \mathrm{~h})$, followed by a linear consumption phase. The consumption rate calculated for this experiment $(0.213 \mathrm{mg}$ of toluene per hour between $26 \mathrm{~h}$ and $40 \mathrm{~h}$ ) corresponded to the sum of the consumption rates by the vermicompost (first experiment) and the earthworms (second experiment). After $40 \mathrm{~h}$, the toluene was fully consumed, showing that the contribution of both vermicompost and earthworms led to a shorter degradation time.

$\mathrm{T}+(\mathrm{C}+\mathrm{X})+\mathrm{W} \longrightarrow \mathrm{T}_{1} \mathrm{C}+\mathrm{T}_{2} \mathrm{~W}+\mathrm{T}_{3}+(\mathrm{X}+\Delta \mathrm{X} 1)+\mathrm{B}$ Equation 6

During the first phase (Equation 6), a part of toluene $\left(\mathrm{T}_{1}\right)$ was adsorbed on the vermicompost, a second part $\left(T_{2}\right)$ was adsorbed on the earthworm surface, a third part $\left(T_{3}\right)$ remained in the 
gaseous phase and the last part $\left(\mathrm{T}-\mathrm{T}_{1}-\mathrm{T}_{2}-\mathrm{T}_{3}\right)$ was consumed by the microorganisms from the vermicompost and leads to an increase in the biomass $\left(\Delta \mathrm{X}_{1}\right)$ and formation of byproducts $(\mathrm{B})$.

$\mathrm{T}_{1} \mathrm{C}+\mathrm{T}_{2} \mathrm{~W}+\mathrm{T}_{3}+\left(\mathrm{X}+\Delta \mathrm{X}_{1}\right)+\mathrm{B} \longrightarrow \mathrm{C}+\left(\mathrm{W}+\Delta \mathrm{W}_{1}\right)+\left(\mathrm{X}+\Delta \mathrm{X}_{1}+\Delta \mathrm{X}_{2}\right)+\mathrm{B}_{1}+\mathrm{D} \quad$ Equation 7 In the second phase (Equation 7), the adsorbed toluene was consumed by both earthworms and biomass leading to an increase in weight, $\left(\Delta \mathrm{W}_{1}\right)$ and $\left(\Delta \mathrm{X}_{2}\right)$ respectively, and the formation of by-products, $(\mathrm{D})$ and $\left(\mathrm{B}_{1}\right)$ respectively, $\left(\mathrm{B}_{1}>\mathrm{B}\right)$.

Hartenstein [46] studied the effect of aromatic compounds on the growth of earthworm Eisenia Fetida and showed that a concentration of $1 \%$ (w/w dry weight) of toluene in activated sludge affected the growth of earthworms and that $4 \%$ of toluene led to $100 \%$ of mortality in 6 weeks. During our experiments, the concentration of toluene did not exceed 3.5 $\mathrm{mg} / 100 \mathrm{~g}$ of vermicompost, i.e. $18 \mathrm{mg} / 100 \mathrm{~g}$ of dry vermicompost $(0.018 \%)$. Moreover, the duration of the exposure of earthworms to polluted vermicompost did not exceed $40 \mathrm{~h}$. So, it was not surprising, all the earthworms were alive and the end of the experiment.

\subsection{Potential mechanisms}

Mechanisms of toluene removal are proposed according to the knowledge on mass transfer and the experimental results of the present study. In the case of the vermicompost alone (Figure 4), the first step was the diffusion of toluene from the gaseous phase to the gas/liquid interface followed by absorption in the biofilm and/or adsorption onto the solid surface. As consumption was recorded simultaneously with the beginning of the experiment, it is supposed that some of the microorganisms, initially present in the vermicompost, could degrade the pollutant without an acclimation period. After the acclimation phase (about $20 \mathrm{~h}$ ), more microorganisms were able to degrade the toluene and the biodegradation rate increased. After toluene degradation (totally or not), by-products could be transferred to the gaseous 
phase. During experiments, no by-product was identified in the gaseous phase. Three hypotheses could explain this fact: (i) the concentration of end-products was under the detection threshold, (ii) oxidation of toluene was total and produced only $\mathrm{CO}_{2}$ and $\mathrm{H}_{2} \mathrm{O}$, (iii) by-products were not released into the gaseous phase.

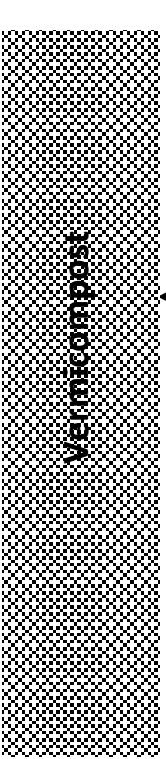

Biofilm

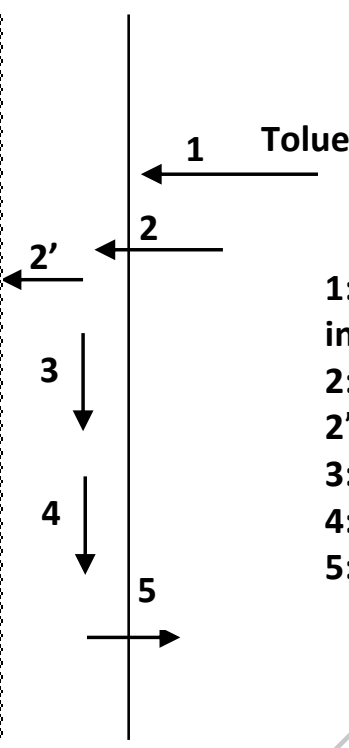

Figure 4: Mechanism of toluene degradation by vermicompost

In the case of earthyorms only (Figure 5), the first step was the diffusion of toluene from the gaseous phase to the mucus that totally covers the skin of the earthworm. As the mucus contains microorganisms, these could degrade the toluene like in the vermicompost. The earthworms used in this study were collected from the laboratory nursery and rinsed before being placed in the conical flask. They were in contact with the vermicompost, so it is supposed that some microorganisms from the vermicompost still remained in the mucus. Moreover, Huang et al. [47] studied the role of earthworm mucus in a vermicomposting system and concluded that the mucus significantly stimulated the microbial activity and 
bacterial abundance. A second degradation route by diffusion through the mucus and transfer to the earthworm body could be considered [48]. Then, the degradation of toluene would occur inside the earthworm. Several hundred bacterial strains belonging to different taxa have been isolated and identified from the digestive tracts of soil and compost earthworms [49]. These authors showed that bacteria associated with earthworm intestines were capable of growth on humic acids as a sole carbon source and that intestinal isolates had elevated activities of proteases and dehydrogenases. These properties suggest that toluene could be oxidized in the earthworm gut. After toluene degradation, in mucus or in the earthworm gut, by-products could be transferred to the gaseous phase. Lanno et at. [50] studied the bioavailability of chemicals in soil for earthworms. According to these authors, during movements through the soil, earthworms encounter and interact with only a specific portion of environmentally available chemicals. Interaction may be through either direct dermal contact with chemicals in the soil solution or soil atmosphere or ingestion of soil or specific fractions of soil. Thus, in the absence of vermicompost, direct dermal contact with the atmosphere loaded with toluene should be taken into account. It is not yet known whether dermal or intestinal uptake is the predominant mechanism for contaminant uptake in earthworms. Pan et al. [51] studied the interaction between earthworm's mucus and the pesticide imidacloprid. They concluded that there is a high affinity of mucus for the organic pollutant but could not confirm whether the mucus serves as a protective barrier against toxic pollutants or promotes the entry of pollutants into the earthworm. Therefore, the degradation of toluene could occur in both the mucus and the gut of the earthworm. 
Mucus

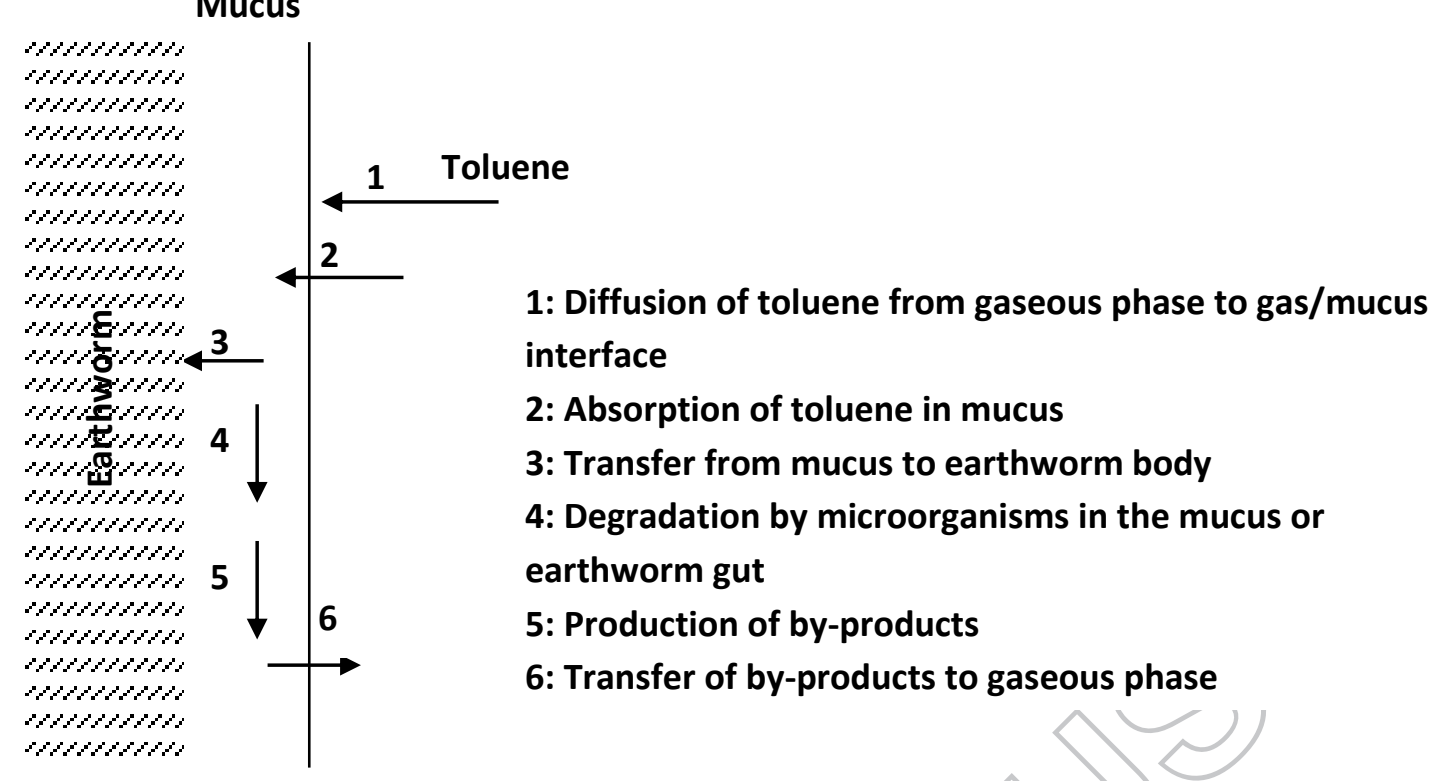

Figure 5: Mechanism of toluene degradation by earthworms

In the case of both vermicompost and earthworms, the same types of degradation might occur.

One more could be added: ingestion of toluene by earthworms through vermicompost ingestion. In this case, toluene could be degraded in the earthworm gut. Figure 6 proposes a combined mechanism of degradation.

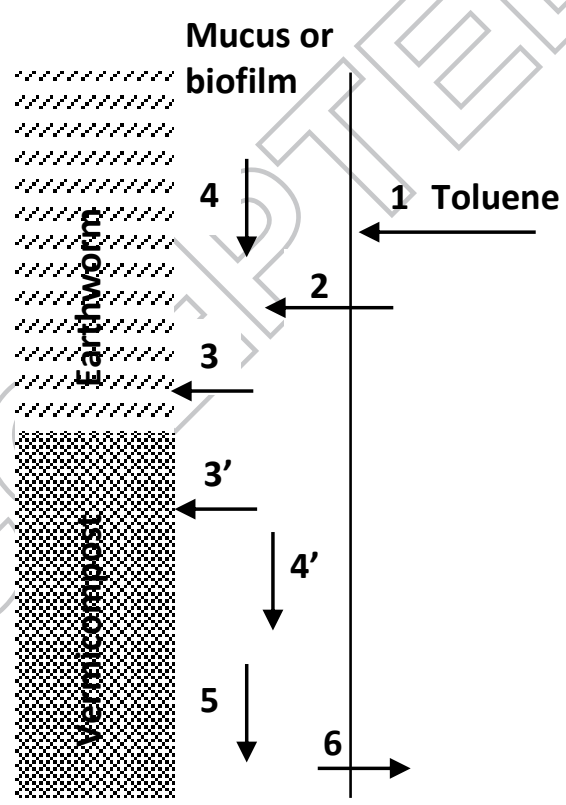

1: Diffusion of toluene from gaseous phase to gas/mucus interface

2: Absorption of toluene in mucus or biofilm

3: Transfer from mucus to earthworm body

3': Transfer onto vermicompost

4: Degradation by microorganisms in the mucus or earthworm gut

4': Degradation by microorganisms in biofilm

5: Production of by-products

6: Transfer of by-products to gaseous phase

Figure 6: Mechanism of toluene degradation by the combination of vermicompost and earthworms 


\section{CONCLUSION}

The results of the batch experiments showed that vermicompost and earthworms were both able to remove toluene at low concentration $(5 \mu \mathrm{L}$ in $1 \mathrm{~L}$ hermetically sealed conical flask). During the batch experiments, no mortality of earthworms was recorded. In the case where the conical flask was filled with a mixture of $100 \mathrm{~g}$ of vermicompost and $10 \mathrm{~g}$ of earthworms, the removal rate $(0.213 \mathrm{mg}$ of toluene per hour between $26 \mathrm{~h}$ and $40 \mathrm{~h}$ of experiment) corresponded to the sum of the consumption rate by $100 \mathrm{~g}$ of vermicompost only and the consumption rate by $10 \mathrm{~g}$ of earthworms only. According to the knowledge on mass transfer and the experimental results, mechanisms of toluene removal have been proposed.

In the case of vermicompost only, it was assumed that the toluene was adsorbed in vermicompost and degraded by the biofilm. In the case of earthworms only, it was assumed that the toluene was absorbed in mucus, then transferred from mucus to earthworms body and that the removal of toluene occurred by microorganisms presents in the mucus and the gut. In the case of both vermicompost and earthworms, all these steps were added together, resulting in an increase of the removal rate.

\section{REFERENCES}

[1] Le Cloirec P. COV (composés organiques volatils). Tech. Ing. 2004 ;Environnement G1 835.

[2] Raghuvanshi S, Majumder S, Gupta S. Biofiltration: Essentials, Research and Applications. Bioremediation Sustain. Wiley-Blackwell; 2012. p. 285-315.

[3] Malhautier L, Khammar N, Bayle S, et al. Biofiltration of volatile organic compounds. Appl. Microbiol. Biotechnol. 2005;68:16-22.

[4] Cohen Y. Biofiltration - the treatment of fluids by microorganisms immobilized into the filter bedding material: a review. Bioresour. Technol. 2001;77:257-274.

[5] Ralebitso-Senior TK, Senior E, Di Felice R, et al. Waste Gas Biofiltration: Advances and Limitations of Current Approaches in Microbiology. Environ. Sci. Technol. 2012; $46: 8542-8573$.

[6] Kim D, Sorial GA. Role of biological activity and biomass distribution in air biofilter performance. Chemosphere. 2007;66:1758-1764.

[7] Ho K-L, Chung Y-C, Lin Y-H, et al. Microbial populations analysis and field application of biofilter for the removal of volatile-sulfur compounds from swine wastewater treatment system. J. Hazard. Mater. 2008;152:580-588.

[8] Jaber MB, Anet B, Amrane A, et al. Impact of nutrients supply and $\mathrm{pH}$ changes on the elimination of hydrogen sulfide, dimethyl disulfide and ethanethiol by biofiltration. Chem. Eng. J. 2014;258:420-426. 
[9] Chan W-C, Lai T-Y. Compounds interaction on the biodegradation of acetone and methyl ethyl ketone mixture in a composite bead biofilter. Bioresour. Technol. 2010;101:126-130.

[10] Gaudin F, Andres Y, Le Cloirec P. Packing material formulation for odorous emission biofiltration. Chemosphere. 2008;70:958-966.

[11] Anet B, Couriol C, Lendormi T, et al. Characterization and Selection of Packing Materials for Biofiltration of Rendering Odourous Emissions. Water. Air. Soil Pollut. 2013;224:1622.

[12] Miller MJ, Allen DG. Transport of hydrophobic pollutants through biofilms in biofilters. Chem. Eng. Sci. 2004;59:3515-3525.

[13] Dumont E, Cabral FDS, Le Cloirec P, et al. Biofiltration using peat and a nutritional synthetic packing material: influence of the packing configuration on $\mathrm{H} 2 \mathrm{~S}$ removal. Environ. Technol. 2013;34:1123-1129.

[14] Morgenroth E, Schroeder ED, Chang DPY, et al. Nutrient Limitation in a Compost Biofilter Degrading Hexane. J. Air Waste Manag. Assoc. 1996;46:300-308.

[15] Delhoménie M-C, Bibeau L, Bredin N, et al. Biofiltration of air contaminated with toluene on a compost-based bed. Adv. Environ. Res. 2002;6:239-254.

[16] Morgan-Sagastume JM, Noyola A, Revah S, et al. Changes in Physical Properties of a Compost Biofilter Treating Hydrogen Sulfide. J Air Waste Manag. Assoc.

2003;53:1011-1021.

[17] Akdeniz N, Janni KA, SalnikovIA. Biofilter performance of pine nuggets and lava rock as media. Bioresour. Technol. 2011;102:4974-4980.

[18] Mupambwa HA, Dube E, Mnkeni PN. Fly ash composting to improve fertiliser value-A review. South Afr. J. Sci. 2015;111:1-6.

[19] Akila D, Ramasubramanian V. Studies on the nutrients status from two different wastes by using Eisenia foetidae. History. 2015;15:42-49.

[20] Juárez PDA, De La Fuente JL, Paulín RV. Vermicomposting as a process to stabilize organic waste and sewage sludge as an application for soil. Tropical and Subtropical Agroecosystems. 2011;14(3):949-963.

[21] Kapoor J, Sharma S, Rana NK. VERMICOMPOSTING FOR ORGANIC WASTE MANAGEMENT. International Journal of Recent Scientific Research. 2015;6:79567960.

[22] Bhattacharya SS, Kim K-H, Ullah MA, et al. The effects of composting approaches on the emissions of anthropogenic volatile organic compounds: A comparison between vermicomposting and general aerobic composting. Environ. Pollut. 2016;208:600-607.

[23] Kumar T, Bhargava R, Prasad KSH, et al. Evaluation of vermifiltration process using natural ingredients for effective wastewater treatment. Ecol. Eng. 2015;75:370-377. 
[24] Bhise H, Anaokar G. Design and Suitability of Modular Vermifilter for Domestic Sewage Treatment. Int. J. 2015;44:44-51.

[25] Lee LH, Wu TY, Shak KPY, et al. Sustainable approach to biotransform industrial sludge into organic fertilizer via vermicomposting: A mini-review. J. Chem. Technol. Biotechnol. 2018;93:925-935.

[26] Singh J, Kaur A. Vermicompost as a strong buffer and natural adsorbent for reducing transition metals, BOD, COD from industrial effluent. Ecol. Eng. 2015;74:13-19.

[27] Prabha LM, Nagalakshmi N, Priya SM. Analysis of nutrient contents in vermicompost. Eur. J. Mol. Biol. Biochem. 2015;2:42-48.

[28] Haynes RJ, Zhou YF. Comparison of the chemical, physical and microbial properties of composts produced by conventional composting or vermicomposting using the same feedstocks. Environ. Sci. Pollut. Res. 2016;1-10.

[29] Fornes F, Mendoza-Hernández D, García-de-la-Fuente R, et al. Composting versus vermicomposting: A comparative study of organic matter evolution through straight and combined processes. Bioresour. Technol. 2012;118:296-305.

[30] Martinez-Balmori D, Spaccini R, Aguiar NO, et al. Molecular characteristics of humic acids isolated from vermicomposts and their relationship to bioactivity. J. Agric. Food Chem. 2014;62:11412-11419.

[31] Anastasi A, Varese GC, Marchisio VF. Isolation and identification of fungal communities in compost and vermicompost. Mycologia. 2005;97:33-44.

[32] Zhu Y, Li S, Luo Y, et al. A biofilter for treating toluene vapors: performance evaluation and microbial counts behavior. PeerJ. 2016;4:e2045.

[33] Morales P, Cáceres M, Scott F, et al. Biodegradation of benzo[ $\alpha]$ pyrene, toluene, and formaldehyde from the gas phase by a consortium of Rhodococcus erythropolis and Fusarium solani. Appl. Microbiol. Biotechnol. 2017

[34] Kim Y-H, Kim K-H. Novel Approach to Test the Relative Recovery of Liquid-Phase Standard in Sorbent-Tube Analysis of Gaseous Volatile Organic Compounds. Anal. Chem. 2012;84:4126-4139.

[35] Chiu C-H, Lin T-F, Young C-C. Short-Term Sorption of Toluene Vapor onto Natural Organic Materials. Water. Air. Soil Pollut. 2003;144:223-241.

[36] Moon K-E, Lee S-Y, Lee SH, et al. Earthworm cast as a promising filter bed material and its methanotrophic contribution to methane removal. J. Hazard. Mater. 2010;176:131-138.

[37] Park S, Lee I, Cho C, et al. Effects of earthworm cast and powdered activated carbon on methane removal capacity of landfill cover soils. Chemosphere. 2008;70:11171123.

[38] Fu Y, Shao L, Liu H, et al. Ethylene removal evaluation and bacterial community analysis of vermicompost as biofilter material. J. Hazard. Mater. 2011;192:658-666. 
[39] Vergara-Fernández A, Lara Molina L, Pulido NA, et al. Effects of gas flow rate, inlet concentration and temperature on the biofiltration of toluene vapors. J. Environ.

Manage. 2007;84:115-122.

[40] Znad HT, Katoh K, Kawase Y. High loading toluene treatment in a compost based biofilter using up-flow and down-flow swing operation. J. Hazard. Mater. 2007; 141:745-752.

[41] Rene ER, Murthy DVS, Swaminathan T. Performance evaluation of a compost biofilter treating toluene vapours. Process Biochem. 2005;40:2771-2779.

[42] Singh RS, Agnihotri SS, Upadhyay SN. Removal of toluene vapour using agro-waste as biofilter media. Bioresour. Technol. 2006;97:2296-2301.

[43] Cheng Z, Lu L, Kennes C, et al. Treatment of gaseous toluene in three biofilters inoculated with fungi/bacteria: Microbial analysis, performance and starvation response. J. Hazard. Mater. 2016;303:83-93.

[44] Wen B, Huang R, Wang P, et al. Effect of Complexation on the Accumulation and Elimination Kinetics of Cadmium and Ciprofloxacin in the Earthworm Eisenia fetida. Environ. Sci. Technol. 2011;45:4339-4345.

[45] Nyholm JR, Asamoah RK, van der Wal L, et al. Accumulation of Polybrominated Diphenyl Ethers, Hexabromobenzene, and 1,2-Dibromo-4-(1,2dibromoethyl)cyclohexane in Earthworm (Eisenia fetida). Effects of Soil Type and Aging. Environ. Sci. Technol. 2010;44:9189-9194.

[46] Hartenstein R. Effect of aromatic compounds, humic acids and lignins on growth of the earthworm eisenia foetida. Soil Biol. Biochem. 1982;14:595-599.

[47] Huang K, Xia H. Role of earthworms' mucus in vermicomposting system: Biodegradation tests based on humification and microbial activity. Sci. Total Environ. 2018;610:703-708.

[48] Edwards CA, Bohlen PJ. Biology and ecology of earthworms. Springer Netherlands. Springer Netherlands; 1995.

[49] Byzov BA, Tikhonov VV, Nechitailo TY, et al. Taxonomic composition and physiological and biochemical properties of bacteria in the digestive tracts of earthworms. Eurasian Soil Sci. 2015;48:268-275.

[50] Lanno R, Wells J, Conder J, et al. The bioavailability of chemicals in soil for earthworms. Ecol. Physiol. Physiochemical Factors Earthworm Ecotoxicol. Third Int. Workshop Earthworm Ecotoxicol. 2004;57:39-47.

[51] Pan X, Song W, Zhang D. Earthworms (Eisenia foetida, Savigny) mucus as complexing ligand for imidacloprid. Biol. Fertil. Soils. 2010;46:845-850. 